\title{
Journal of Analytical, Bioanalytical and Separation Techniques
}

ISSN: 2476-1869

\section{Biofield Energy Treatment: Physicochemical and Thermal Characterization of L-Tryptophan}

\author{
Alice Branton $^{1}$, Mahendra Kumar Trivedi ${ }^{1}$, Dahryn Trivedi ${ }^{1}$, Gopal Nayak ${ }^{1}$, Snehasis Jana ${ }^{2 *}$ \\ ${ }^{1}$ Trivedi Global, Inc., Henderson, USA \\ ${ }^{2}$ Trivedi Science Research Laboratory Pvt. Ltd., Bhopal, India
}

*Corresponding author: Snehasis Jana, Trivedi Science Research Laboratory Pvt. Ltd., Bhopal, India, Tel: +91-022-25811234;

E-mail: publication@trivedieffect.com

\begin{abstract}
L-tryptophan is an essential amino acid that needs to be supplemented through protein-rich diet and it helps in growth and nitrogen balance in the humans. The aim of this studyis to evaluate the effect of the Trivedi Effect ${ }^{\circledR}$-Consciousness Energy Healing Treatment on the L-tryptophan in terms of its physicochemical and thermal properties by usingmodern analytical techniques. The method involved dividing the testsample into two parts and providing the Consciousness Energy Healing Treatmentto one part (named as Biofield Energy Treated sample), remotely by a renowned Biofield Energy Healer, Dahryn Trivedi; while the other part didn't receive any treatment called a control sample. The particle size values of the treated sample was increased by $4.77 \%(\mathrm{~d} 10), 6.37 \%(\mathrm{~d} 50), 6.72 \%(\mathrm{~d} 90)$, and $6.49 \%\{\mathrm{D}(4,3)\}$; thus, the specific surface area was increased by $4.35 \%$ comparedto the control sample. The PXRD peak intensitiesand crystallite sizes of the treated sample were significantly altered ranging from $-82.69 \%$ to $30.54 \%$ and $-17.15 \%$ to $179.73 \%$, respectively, in comparison to the control sample. The total weight loss of the treated sample was significantly reduced by $11.60 \%$ during the heating process that resulted in a significant increase in the residual amount of the sample by $1093.33 \%$ as compared to the control sample. The melting temperature and the latent heat of fusion of the treated sample was significantly increased by $1.12 \%$ and $6.79 \%$, respectively, compared to the untreated sample. Hence, the L-tryptophan might forma new polymorph after the Trivedi Effect ${ }^{\circledR}$-Consciousness Energy Healing Treatment that may possess better solubility and bioavailability profile along with improved thermal stability compared with the untreated sample. Thus, the Trivedi Effect ${ }^{\circledR}$-Consciousness Energy Healing Treatment could be considered as a novel approach for designing the formulations with improved drug profile and efficacy. The treated L-tryptophan would be more useful for the treatment of mental health disorders, premenstrual dysphoric disorder (PMDD), attention deficit-hyperactivity disorder (ADHD), obsessive-compulsive disorder, depression, and bipolar disorder, etc.
\end{abstract}

Keywords: Complementary and alternative medicine; L-tryptophan; Consciousness Energy Healing Treatment; The Trivedi Effect ${ }^{\circledR}$; PXRD; TGA/DTG; DCS

\section{Introduction}

Tryptophan was first isolated from casein protein and discovered by Hopkins and Cole in the early $1900 \mathrm{~s}^{[1]}$, while its molecular structure was determined later by Ellinger and Flamand ${ }^{[2]}$. In amino acids, the L isomer (e.g., L-tryptophan) is used in protein synthesis and has the ability to pass the blood-brain barrier ${ }^{[3,4]}$. L-tryptophan is available in the lowest concentration in the human body among all amino acids ${ }^{[5]}$ and has low tissue storage ${ }^{[6]}$. Although it is needed in small amounts in the body for general healthy nutrition; however it is the essential amino acid that needs to be supplied through the $\operatorname{diet}^{[7,8]}$. The rich sources of tryptophan include protein-based foods and dietary proteins ${ }^{[9]}$ such as dairy, meats, fruits, and seeds, etc. Besides, the meals having high-glycaemic index also increase its availability within the body ${ }^{[10]}$. Tryptophan not only works in the protein formation, but it is also a precursor for various metabolites, such as kynurenine and serotonin. Serotonin is a neurotransmitter that is produced cen-
Received date: January 4, 2019

Accepted date: February 6, 2019

Published date: February 13, 2019

Citation: Snehasis, J., et al. Biofield Energy Treatment: Physicochemical and Thermal Characterization of L-Tryptophan. (2019) J Anal Bioanal Separation Tech 4(1): 7- 13.

Copyright: (C) 2019 Jana, S. This is an Open access article distributed under the terms of Creative Commons Attribution 4.0 International License. 
Citation: Snehasis, J., et al. Biofield Energy Treatment: Physicochemical and Thermal Characterization of L-Tryptophan. (2019) J Anal Bioanal Separation Tech 4(1): 7- 13 .

trally as well as peripherally by its sole precursor, tryptophan ${ }^{[11]}$. Besides, the kynurenine synthesis is considered the second most important metabolic pathway that is responsible for approximately $90 \%$ of tryptophan metabolism ${ }^{[12]}$. Kynurenine acts as the precursor of kynurenic acid, which has the antagonist properties for the glutamate ionotropic receptors. There are other bioactive compounds for which tryptophan acts as the in vivo precursor such as, tryptamine, nicotinamide (vitamin B6), melatonin, 3-hydroxykynurenine, and xanthurenic and quinolinic acids ${ }^{[13]}$. Since tryptophan can only be taken through the diet ${ }^{[14]}$; thus, its presence in the blood could be highly influenced by the dietary factors. Also, the other amino acids can affect its uptake in the brain, and thereby the rate of formation of serotonin ${ }^{[15]}$. The reduced levels of L-tryptophan in the body may cause bipolar disorder, depression ${ }^{[16]}$, and obsessive-compulsive disorder, etc ${ }^{[17]}$. Hence, it is given in the form of nutraceutical/pharmaceutical formulations to fulfill the need. Besides, it could also be used in the field of alternative medicine to help people quit smoking ${ }^{[18]}$ and in the treatment of mood swings and irritability due to the premenstrual dysphoric disorder syndrome ${ }^{[19]}$ as an aid.

The bioavailability of any compound is highly influenced by its physicochemical properties that could be altered to improve its solubility, dissolution, and absorption within the body ${ }^{[20]}$, and thereby to attain the maximum biological activities $^{[21]}$. Consciousness Energy Healing Treatment is one among such novel approaches that showed its significant role in modifying the physicochemical and thermal properties of various compounds ${ }^{[22,23]}$. The use of Energy therapy such as, the Biofield Energy Treatment, against various diseases has been evident now a days as it was found to have advantageous effect and therefore, accepted by the National Center for Complementary and Alternative Medicine (NCCAM) under the field of Complementary and Alternative Medicine (CAM) therapies along with homeopathy, yoga, meditation, acupressure, acupuncture, healing touch, relaxation techniques, hypnotherapy, Pilates, Reiki, Ayurvedic medicine, cranial sacral therapy, traditional Chinese herbs and medicines, etc ${ }^{[24,25]}$. The Trivedi Effect ${ }^{\mathbb{}}$-Consciousness Energy Healing Treatment has already been reported in various literature for its significant effect on the physicochemical properties of the pharmaceuticals/nutraceuticals ${ }^{[26-28]}$, metals, ceramics, and chemicals ${ }^{[29-31]}$, antimicrobial activity ${ }^{[32-34]}$, agricultural productivity ${ }^{[35,36]}$, and in the field of biotechnology[ ${ }^{[37,38]}$, cancer research $^{[39]}$, and skin and bone health ${ }^{[40-42]}$, etc. In this regard, this research work was designed to analyze the impact of the Biofield Energy Treatment on the physicochemical and thermal characteristics of L-tryptophan with the help of various analytical techniques.

\section{Materials and Methods}

\section{Chemicals and Reagents}

L-tryptophan was purchased from Alfa Aesar, the USA and the other chemicals were of analytical grade purchased in India.

\section{Consciousness Energy Healing Treatment Strategies}

The experimental design includes dividing the L-tryptophan sample into two parts, among which the one part was not provided the Biofield Energy Treatment, and considered as the control sample. Besides, the other part of the sample was exposed to the
Trivedi Effect ${ }^{\mathbb{B}}$ - Consciousness Energy Healing Treatment for 3 minutes under standard laboratory conditions by the renowned Biofield Energy Healer, Dahryn Trivedi, USA, and known as the Biofield Energy Treated sample. Then, for comparison purpose, the control sample was treated by a "sham" healer, who did not have any knowledge about the Biofield Energy Treatment. The control and the Biofield Energy Treated samples were then stored in sealed conditions and characterized further by using PSA, PXRD, DSC, and TGA/DTG analytical techniques.

\section{Characterization}

The PSA, PXRD, TGA/DTG, and DSCanalysis of L-tryptophan were performed. The PSA was performed using Malvern Master sizer 2000, from the UK with a detection range between 0.01 $\mu \mathrm{m}$ to $3000 \mu \mathrm{m}$ using the wet method ${ }^{[43,44]}$. The PXRD analysis of L-tryptophan powder sample was performed with the help of Rigaku MiniFlex-II Desktop X-ray diffractometer (Japan) ${ }^{[45,46]}$. The average size of crystallites was calculated from PXRD data using the Scherrer's formula (1)

$\mathrm{G}=\mathrm{k} \lambda / \beta \cos \theta$

Where $\mathrm{G}$ is the crystallite size in $\mathrm{nm}, \mathrm{k}$ is the equipment constant $(0.94), \lambda$ is the radiation wavelength $(0.154056 \mathrm{~nm}$ for $\mathrm{K} \alpha 1$ emission), $\beta$ is the full-width at half maximum, and $\theta$ is the Bragg angle ${ }^{[4]}$.

The TGA/DTG thermograms of L-tryptophan were obtained with the help of TGA Q50 TA instruments. Similarly, the DSC analysis of L-tryptophan was performed with the help of DSC Q200, TA instruments ${ }^{[48]}$.

The $\%$ change in particle size, specific surface area (SSA), peak intensity, crystallite size, melting point, latent heat, weight loss and the maximum thermal degradation temperature (Tmax) of the Biofield Energy Treated sample was calculated compared with the control sample using the following equation 2 :

$\%$ change $=[$ Treated-Control $] /$ Control $\times 100$

\section{Results and Discussion}

\section{Particle Size Analysis (PSA)}

The particle size distribution data were presented in Table 1 that helps in analysing the effect of the Biofield Energy Treatment on the treated sample as compared to the control sample. The treated L-tryptophan sample showed a significant reduction in the particle size values at $d_{10}(4.77 \%), d_{50}(6.37 \%), d_{90}(6.72 \%)$, and $\mathrm{D}(4,3)(6.49 \%)$ compared to the control sample (Table 1$)$. The significant decrease in the particle size values of the treated sample resulted in $4.35 \%$ increase in the specific surface area $\left(0.096 \mathrm{~m}^{2} / \mathrm{g}\right)$, compared to the control sample $\left(0.092 \mathrm{~m}^{2} / \mathrm{g}\right)$.

Table 1: Particle size distribution of the control and Biofield Energy Treated L-tryptophan

\begin{tabular}{|l|l|l|l|l|l|}
\hline Parameter & $\begin{array}{l}\mathrm{d}_{10} \\
(\mu \mathrm{m})\end{array}$ & $\begin{array}{l}\mathrm{d}_{50} \\
(\mu \mathrm{m})\end{array}$ & $\begin{array}{l}\mathrm{d}_{90} \\
(\mu \mathrm{m})\end{array}$ & $\begin{array}{l}\mathrm{D}(4,3) \\
(\mu \mathrm{m})\end{array}$ & $\begin{array}{l}\mathrm{SSA} \\
\left(\mathrm{m}^{2} / \mathrm{g}\right)\end{array}$ \\
\hline Control & 28.75 & 146.72 & 371.33 & 177.03 & 0.092 \\
\hline Biofield Energy Treated & 27.38 & 137.37 & 346.38 & 165.54 & 0.096 \\
\hline Percent change (\%) & -4.77 & -6.37 & -6.72 & -6.49 & 4.35 \\
\hline
\end{tabular}


$\mathrm{d}_{10}, \mathrm{~d}_{50}$, and $\mathrm{d}_{90}$ : particle diameter corresponding to $10 \%, 50 \%$, and $90 \%$ of the cumulative distribution, $\mathrm{D}(4,3)$ : the average mass-volume diameter, and SSA: the specific surface area.

Various techniques have been used now a days to improve the solubility and bioavailability of the drug molecule and one among them is to modify the particle size of the crystalline compound and thereby to increase the surface area ${ }^{[49]}$. The reduced particle size of the drug ultimately increases the surface area available for salvation ${ }^{[50]}$. Thus, the increased surface area of the L-tryptophan sample after the Biofield Energy Treatment might improve the solubility, and thereby the absorption and bioavailability compared with the untreated sample.

\section{Powder X-ray Diffraction (PXRD) Analysis}

The PXRD analysis of the control and the treated L-tryptophan samples was done and the resulted diffractograms were recorded (Figure 1) and analysed with respect to the differences observed in terms of the relative intensities and crystallite sizes between the samples (Table 2). The diffractograms of both the samples revealed the presence of sharp and intense peaks that indicated the crystalline nature of the control and treated sample; however, some alterations were observed in the Bragg's angles of the peaks of the treated sample in comparison to the control sample. The treated sample also showed significant alterations in the peak intensities and crystallite sizes corresponding to the characteristic peaks in the range from $-82.69 \%$ to $30.54 \%$ and $-17.15 \%$ to $179.73 \%$, respectively, compared to the control sample. The changes in the Bragg's angles, peak intensities, and crystallite sizes compared to the untreated sample suggested the possible formation of a new polymorph of L-tryptophan due to the Biofield Energy Treatment ${ }^{[51]}$, which might have better solubility and bioavailability profile ${ }^{[52]}$ compared with the control sample.
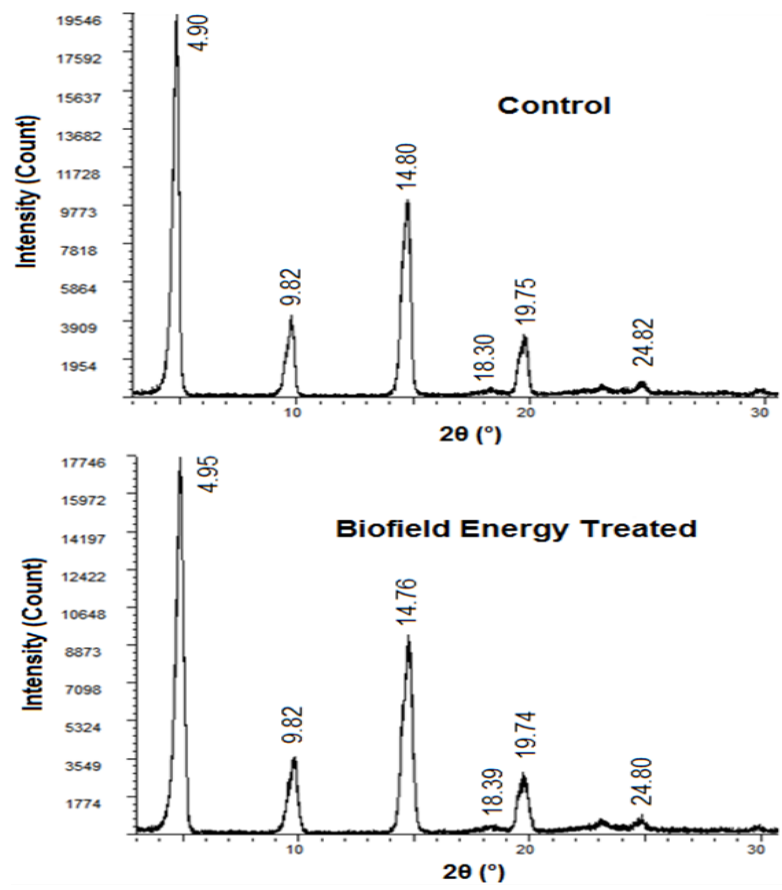

Figure 1: PXRD diffractograms of the control and Biofield Energy Treated L-tryptophan.

Table 2: PXRD data for the control and Biofield Energy Treated L-tryptophan

\begin{tabular}{|l|l|l|l|l|l|l|l|l|}
\hline \multirow{2}{*}{ Entry No. } & \multicolumn{4}{l}{ Bragg angle $\left({ }^{\circ} 2 \theta\right)$} & \multicolumn{3}{l|}{ Intensity $(\mathrm{cps})$} & \multicolumn{3}{l|}{ Crystallite size $(\mathrm{G}, \mathrm{nm})$} \\
\cline { 2 - 10 } & Control & Treated & Control & Treated & \% change & Control & Treated & \% change \\
\hline 1 & 4.90 & 4.95 & 4622 & 5045 & 9.15 & 261.3 & 216.5 & -17.15 \\
\hline 2 & 9.82 & 9.82 & 1116 & 1091 & -2.24 & 208.9 & 174.7 & -16.37 \\
\hline 3 & 14.80 & 14.76 & 2341 & 3056 & 30.54 & 208.1 & 173.1 & -16.82 \\
\hline 4 & 18.30 & 18.39 & 131 & 100 & -23.66 & 92.0 & 104.0 & 13.04 \\
\hline 5 & 19.75 & 19.74 & 859 & 869 & 1.16 & 205.0 & 173.3 & -15.46 \\
\hline 6 & 24.82 & 24.80 & 624 & 108 & -82.69 & 74.0 & 207.0 & 179.73 \\
\hline
\end{tabular}


Citation: Snehasis, J., et al. Biofield Energy Treatment: Physicochemical and Thermal Characterization of L-Tryptophan. (2019) J Anal Bioanal Separation Tech 4(1): 7- 13 .

Thermal Gravimetric Analysis (TGA)/ Differential Thermogravimetric Analysis (DTG)

The TGA/DTG techniques help in determining the impact of the Biofield Energy Treatment on the thermal degradation pattern of the L-tryptophan sample. The scientific studies on thermogravimetric analysis of L-tryptophan reported a fast mass loss starting at $526-538 \mathrm{~K}$ followed by its thermal degradation and thereby the production of $\mathrm{CO}_{2}, \mathrm{NH}_{3}$, and $\mathrm{H}_{2} \mathrm{O}$ molecules during the whole decomposition process ${ }^{[3]}$. The observed TGA thermograms of the control and the treated L-tryptophan samples (Figure 2) were observed in the similar temperature range. The further data indicated the reduction in the total weight loss of the treated sample by $11.60 \%$ during the thermal degradation process (Table 3 ). As a result, the residue weight of the treated L-tryptophan sample (12.53\%) showed a significant increase by $1093.33 \%$ (Table 3 ) in comparison to the control sample $(1.05 \%)$. Thus, the TGA result showed the significant increase in the thermal stability of the treated sample after the Biofield Energy Treatment, compared to the control sample.

Table 3: TGA/DTG data of the control and Biofield Energy Treated samples of L-tryptophan

\begin{tabular}{|l|l|l|l|l|}
\hline Sample & \multicolumn{2}{|l|}{ TGA } & \multicolumn{2}{l|}{ DTG } \\
\hline & $\begin{array}{l}\text { Total weight } \\
\text { loss }(\%)\end{array}$ & Residue \% & $\begin{array}{l}\text { Peak 1 } \\
\mathrm{T}_{\max }\left({ }^{\circ} \mathrm{C}\right)\end{array}$ & $\begin{array}{l}\text { Peak 2 } \\
\mathrm{T}_{\text {max }}\left({ }^{\circ} \mathrm{C}\right)\end{array}$ \\
\hline Control & 98.95 & 1.05 & 285.61 & 390.89 \\
\hline $\begin{array}{l}\text { Biofield Energy } \\
\text { Treated }\end{array}$ & 87.47 & 12.53 & 286.00 & 393.42 \\
\hline \% Change* & -11.60 & 1093.33 & 0.14 & 0.65 \\
\hline
\end{tabular}

$\mathrm{T}_{\max }=$ the temperature at which maximum weight loss takes place in $\mathrm{TG}$ or peak temperature in DTG
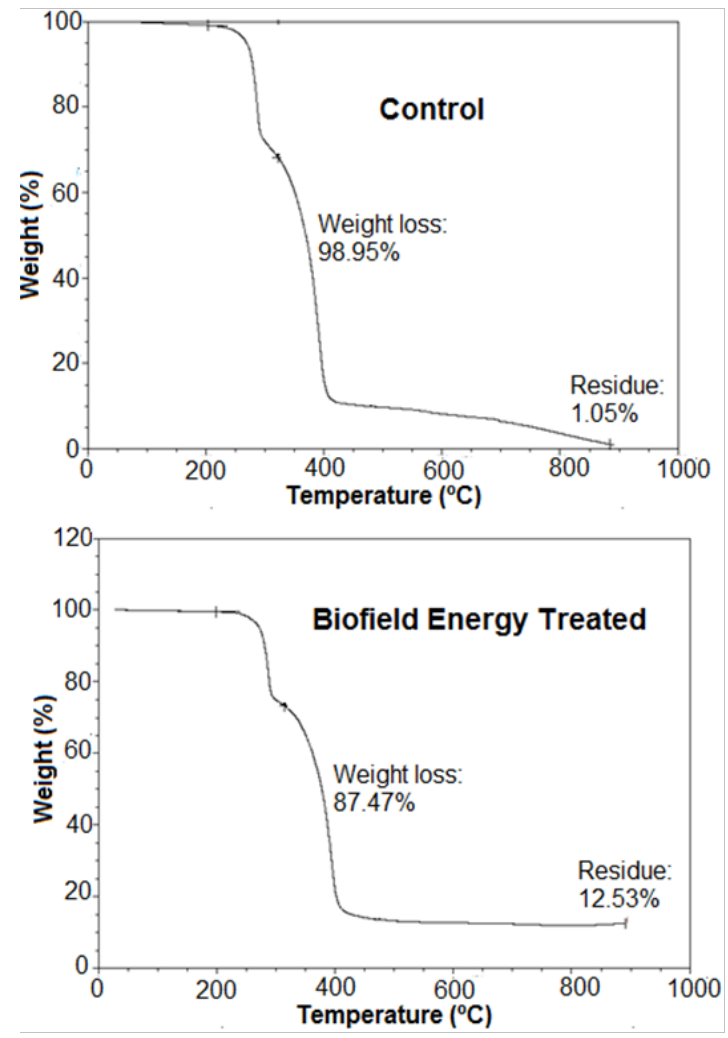

Figure 2: TGA thermograms of the control and Biofield Energy Treated L-tryptophan.
Besides, the DTG thermograms (Figure 3) of both the samples showed two peaks that represent the maximum thermal degradation temperatures $\left(\mathrm{T}_{\max }\right)$. The $\mathrm{T}_{\max }$ of the treated sample corresponding to 1 st and 2 nd peaks were observed to be slightly increased by $0.14 \%$ and $0.65 \%$, respectively, compared to the control sample. Thus, the DTG data support the TGA results as the increase in $\mathrm{T}_{\max }$ temperatures indicated the increase in thermal stability of the treated L-tryptophan sample compared to the untreated sample. Overall, the TGA/DTG results showed that the thermal stability of the treated sample was improved after the Biofield Energy Treatment compared to the untreated sample that might help in providing the better storage conditions ${ }^{[54]}$.
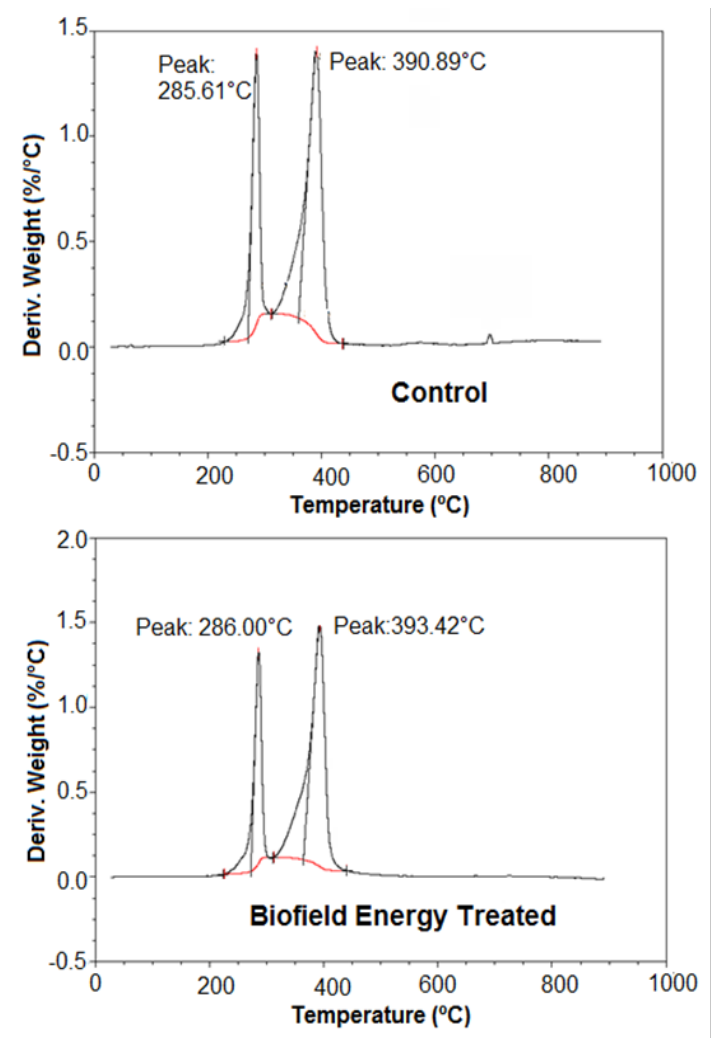

Figure 3: DTG thermograms of the control and Biofield Energy Treated L-tryptophan.

\section{Differential Scanning Calorimetry (DSC) Analysis}

The DSC technique helps to analyze the endothermic and exothermic events that may occur during the heating of samples along with the enthalpy change during the process ${ }^{[55]}$. The scientific studies reported the presence of a single endothermic peak in the DSC thermogram of L-tryptophan in the temperature range of 540-577 $\mathrm{K}$ during its melting as a result of the heating process $^{[56]}$. 

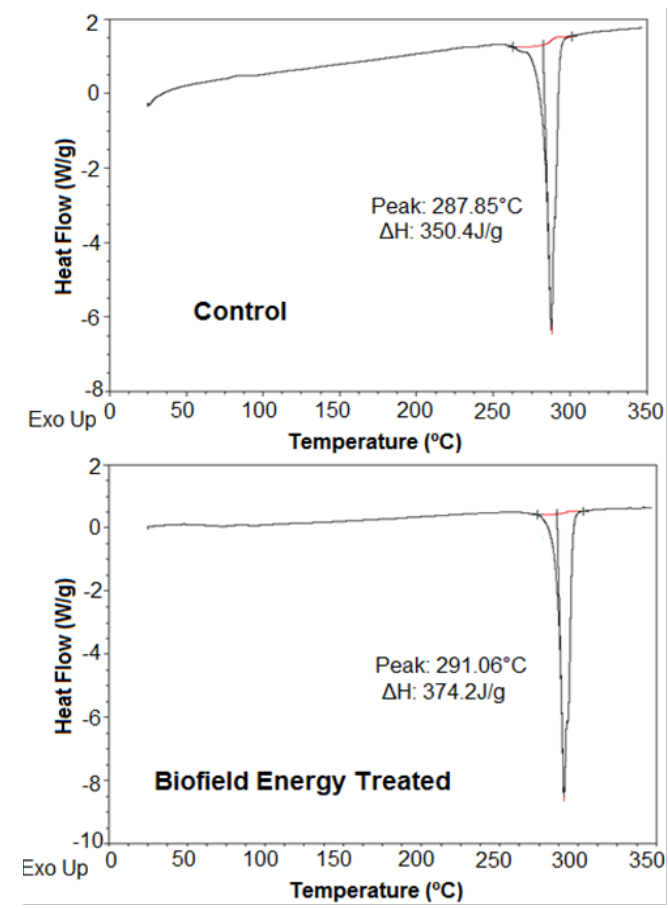

Figure 4: DSC thermograms of the control and Biofield Energy Treated L-tryptophan.

The control and the treated sample of L-tryptophan also showed the single endothermic peak in their respective DSC thermograms in the similar temperature range as reported in the literature and the peaks were considered as the melting peak. The data of the DSC thermograms revealed significant alterations in the melting temperature and corresponding $\Delta \mathrm{H}_{\text {fusion }}$ of the treated sample in comparison to the control sample. The melting peak of the control sample was observed at $287.85^{\circ} \mathrm{C}$ that was shifted to $\sim 4^{\circ} \mathrm{C}$ in the treated sample and was found at $291.06^{\circ} \mathrm{C}$. It indicated the significant increase $(1.12 \%)$ in the melting temperature of the treated sample after the Biofield Energy Treatment along with $6.79 \%$ increase in the $\Delta \mathrm{H}_{\text {fusion }}$ as compared to the control sample (Table 4).

Table 4: DSC data for the control and Biofield Energy Treated samples of L-tryptophan

\begin{tabular}{|l|l|l|}
\hline Sample & Peak Temperature $\left({ }^{\circ} \mathrm{C}\right)$ & $\Delta \mathrm{H}(\mathrm{J} / \mathrm{g})$ \\
\hline Control Sample & 287.85 & 350.40 \\
\hline Biofield Energy Treated & 291.06 & 374.20 \\
\hline \% Change & 1.12 & 6.79 \\
\hline
\end{tabular}

$\Delta \mathrm{H}$ : Latent heat of fusion

Such significant changes in the melting temperature and latent heat of the treated L-tryptophan sample indicated the improved thermal stability as well as some possible alterations crystalline structure of the L-tryptophan due to the Biofield Energy Treatment ${ }^{[57]}$ in comparison to the untreated sample.

\section{Conclusions}

The study was done to analyze the effect of the Trivedi Effect $^{\circledR}$-Consciousness Energy Healing Treatment on the physicochemical and thermal characteristics of L-tryptophan. The particle size values of the Biofield Energy Treated sample was increased by $4.77 \%\left(\mathrm{~d}_{10}\right), 6.37 \%\left(\mathrm{~d}_{50}\right), 6.72 \%\left(\mathrm{~d}_{90}\right)$, and $6.49 \%$ $\{\mathrm{D}(4,3)\}$; thus, the specific surface area was increased by $4.35 \%$ compared to the control sample. The PXRD peak intensities and crystallite sizes of the treated sample were significantly altered ranging from $-82.69 \%$ to $30.54 \%$ and $-17.15 \%$ to $179.73 \%$, respectively, in comparison to the control sample. The total weight loss of the Biofield Energy Treated sample was significantly reduced by $11.60 \%$ during the heating process that resulted in a significant increase in the residual amount of the sample by $1093.33 \%$ as compared to the control sample. The melting temperature and $\Delta \mathrm{H}_{\text {fusion }}$ of the Biofield Energy Treated sample was significantly increased by $1.12 \%$ and $6.79 \%$, respectively, compared to the untreated sample. Hence, it also indicated the improved thermal stability of the Biofield Energy Treated sample along with some significant changes in the molecular chain pattern compared to the untreated sample. The overall results showed that the Trivedi Effect ${ }^{\mathbb{B}}$-Consciousness Energy Healing Treatment has altered the physicochemical and thermal properties of the L-tryptophan sample significantly that might help in improving the solubility, dissolution, bioavailability, and thermal stability of the L-tryptophan sample as compared to the control sample. Therefore, the approach of L-tryptophan formulation development using the Biofield Energy Treatment could be beneficial regarding the treatment of various diseases such as mental health disorders, premenstrual dysphoric disorder (PMDD), attention deficit-hyperactivity disorder (ADHD), obsessive-compulsive disorder, depression, and bipolar disorder, etc.

Acknowledgements: The authors are grateful to Central Leather Research Institute, SIPRA Lab. Ltd., Trivedi Science, Trivedi Global, Inc., Trivedi Testimonials, and Trivedi Master Wellness for their assistance and support during this work.

\section{References}

1. Hopkins, F.G., Cole, S.W. A contribution to the chemistry of proteids: Part I. A preliminary study of a hitherto undescribed product of tryptic digestion. (1901) J Physiol 27(4-5): 418-428. PubMed | CrossRef | Others

2. Ellinger, A., Flamand, C. Uber syntetischgewonnes tryptophan und einige seiner derivate. (1908) Hoppe-Selye's Z Physiol Chemistry 55: 8-24.

PubMed $\mid$ CrossRef $\mid$ Others

3. Pardridge, W.M., Oldendorf, W.H. Kinetic analysis of blood-brain barrier transport of amino acids. (1975) Biochim Biophys Acta 401(1): 128-136.

PubMed | CrossRef | Others

4. Richard, D.M., Dawes, M.A., Mathias, C.W., et al. L-tryptophan: Basic Metabolic Functions, Behavioral Research and Therapeutic Indications. (2009) Int J Tryptophan Res 2: 45-60.

PubMed | CrossRef | Others

5. Young, V.R. Adult amino acid requirements: The case for a major revision in current recommendations. (1994) J Nutr 124(8 Suppl): 1517S-1523S.

PubMed | CrossRef | Others

6. Reilly, J.G., McTavish, S.F.B., Young, A.H. Rapid depletion of plasma tryptophan: A review of studies and experimental methodology. (1997) J Psychopharmacol 11(4): 381-392. 
Citation: Snehasis, J., et al. Biofield Energy Treatment: Physicochemical and Thermal Characterization of L-Tryptophan. (2019) J Anal Bioanal Separation Tech 4(1): 7- 13 .

PubMed | CrossRef $\mid$ Others

7. Sainio, E.L., Pulkki, K., Young, S.N. L-tryptophan: Biochemical, nutritional and pharmacological agents. (1996) Amino Acids 10(1): 21-47.

PubMed |CrossRef | Others

8. Matarese, L.E., Gottschlich, M.M. Proteins and amino acids. Contemporary Nutrition Support Practice, $2^{\text {nd }}$ ed. Saunders, New York, 2003.

PubMed $\mid$ CrossRef $\mid$ Others

9. Friedman, M., Levin, C.E. Nutritional and medicinal aspects of d-amino acids. (2012) Amino Acids 42(5):1553-1582.

PubMed | CrossRef | Others

10. Herrera, C.P., Smith, K., Atkinson, F., et al. High-glycaemic index and -glycaemic load meals increase the availability of tryptophan in healthy volunteers. (2011) Br J Nutr 105(11): 1601-1606. PubMed | CrossRef | Others

11. Richard, D.M., Dawes, M.A., Mathias, C.W., et al. L-tryptophan: Basic metabolic functions, behavioral research and therapeutic indications. (2009) Int J Tryptophan Res 2: 45-60. PubMed | CrossRef | Others

12. Stone, T.W., Darlington, L.G. Endogenous kynurenines as targets for drug discovery and development. (2002) Nat Rev Drug Discov 1(8): 609-620. PubMed |CrossRef | Others

13. Friedman, M. Analysis, Nutrition, and Health Benefits of Tryptophan. (2018) Int J Tryptophan Res 11: 1178646918802282. PubMed | CrossRef | Others

14. Soh, N., Walter, G. Tryptophan and depression: Can diet alone be the answer? (2011) Acta Neuropsychiatr 23(1): 3-11. PubMed |CrossRef | Others

15. Lindseth, G., Helland, B., Caspers, J. The effects of dietary tryptophan on affective disorders. (2014) Arch Psychiatr Nurs 29(2): 102-107. PubMed |CrossRef | Others

16. Ledochowski, M., Sperner-Unterweger, B., Widner, B., et al. Fructose malabsorption is associated with early signs of mental depression. (1998) Eur J Med Res 3(6): 295-298. PubMed | CrossRef | Others

17. Maron, E., Shlik, J., Nutt, D.J. Tryptophan Research in Panic Disorder. (2008) Int J Tryptophan Res 1: 3-12.

PubMed | CrossRef $\mid$ Others

18. Bowen, D.J., Spring, B., Fox, E.Tryptophan and high-carbohydrate diets as adjuncts to smoking cessation therapy. (1991) J Behav Med 14(2): 97-110. PubMed |CrossRef $\mid$ Others

19. Freeman, E.W., Sondheimer, S.J. Premenstrual Dysphoric Disorder: Recognition and Treatment. (2003) Prim Care Companion J Clin Psychiatry 5(1): 30-39. PubMed | CrossRef $\mid$ Others

20. Mulla, S.I., Hu, A., Sun, Q., et al. Biodegradation of sulfamethoxazole in bacteria from three different origins. (2018) J Environ Manage 206: 93-102. PubMed |CrossRef | Others

21. Andrysek, T. Impact of physical properties of formulations on bioavailability of active substance: current and novel drugs with cyclosporine. (2003) Mol Immunol 39(17-18): 1061-1065. PubMed | CrossRef | Others

22. Trivedi, M.K., Branton, A., Trivedi, D., et al. Evaluation of the isotopic abundance ratio in biofield energy treated resorcinol using gas chromatography-mass spectrometry technique. (2016) Pharm
Anal Acta 7: 481.

PubMed $\mid$ CrossRef $\mid$ Others

23. Trivedi, M.K., Branton, A., Trivedi, D., et al. Spectroscopic characterization of disodium hydrogen orthophosphate and sodium nitrate after biofield treatment. (2015) J Chromatogr Sep Tech 6: 282.

PubMed | CrossRef $\mid$ Others

24. Berman, J.D., Straus, S.E. Implementing a research agenda for complementary and alternative medicine. (2004) Annu Rev Med 55: 239-254.

PubMed |CrossRef | Others

25. Barnes, P.M., Bloom, B., Nahin, R.L. Complementary and alternative medicine use among adults and children: United States, 2007. (2008) Natl Health Stat Report 12: 1-23.

PubMed $\mid$ CrossRef $\mid$ Others

26. Trivedi, M.K., Patil, S., Shettigar, H., et al. Effect of biofield treatment on spectral properties of paracetamol and piroxicam. (2015) Chem Sci J 6: 98.

PubMed | CrossRef $\mid$ Others

27. Trivedi, M.K., Tallapragada, R.M., Branton, A., et al. Potential impact of biofield treatment on atomic and physical characteristics of magnesium. (2015) Vitam Miner 3: 129.

PubMed | CrossRef $\mid$ Others

28. Trivedi, M.K., Branton, A., Trivedi, D., et al. A Systematic study of the biofield energy healing treatment on physicochemical, thermal, structural, and behavioral properties of magnesium gluconate. (2017) Int J Bioorganic Chem 2(3): 135-145.

PubMed $\mid$ CrossRef $\mid$ Others

29. Trivedi, M.K., Patil, S., Tallapragada, R.M. Effect of biofield treatment on the physical and thermal characteristics of vanadium pentoxide powders. (2013) J Material Sci Eng S 11: 001. PubMed $\mid$ CrossRef $\mid$ Others

30. Trivedi, M.K., Branton, A., Trivedi, D., et al. Gas chromatographymass spectrometry based isotopic abundance ratio analysis of biofield energy treated methyl-2-napthylether (Nerolin). (2016) Am J Phy Chem 5(4): 80-86.

PubMed | CrossRef | Others

31. Trivedi, M.K., Tallapragada, R.M., Branton, A., et al. Characterization of physical and structural properties of aluminum carbide powder: Impact of biofield treatment. (2015) J Aeronaut Aerospace Eng 4: 142.

PubMed $\mid$ CrossRef $\mid$ Others

32. Trivedi, M.K., Branton, A., Trivedi, D., et al. Phenotyping and 16S rDNA analysis after biofield treatment on Citrobacter braakii: A urinary pathogen. (2015) J Clin Med Genom 3: 129.

PubMed | CrossRef $\mid$ Others

33. Trivedi, M.K., Patil, S., Shettigar, H., et al. Evaluation of biofield modality on viral load of Hepatitis B and C viruses. (2015) J Antivir Antiretrovir 7: 083-088.

PubMed | CrossRef $\mid$ Others

34. Trivedi, M.K., Patil, S., Shettigar, H., et al. An impact of biofield treatment: Antimycobacterial susceptibility potential using BACTEC 460/MGIT-TB System. (2015) Mycobact Dis 5: 189.

PubMed | CrossRef $\mid$ Others

35. Trivedi, M.K., Branton, A., Trivedi, D., et al. Agronomic characteristics, growth analysis, and yield response of biofield treated mustard, cowpea, horse gram, and groundnuts. (2015) Int J Genetics Genom 3: 74-80.

PubMed |CrossRef $\mid$ Others

36. Trivedi, M.K., Branton, A., Trivedi, D., et al. Evaluation of 
plant growth, yield and yield attributes of biofield energy treated mustard (Brassica juncea) and chick pea (Cicerarietinum) seeds. (2015) Agricult, Forestry Fisheries 4: 291-295. PubMed | CrossRef | Others

37. Trivedi, M.K., Patil, S., Shettigar, H., et al. Phenotypic and biotypic characterization of Klebsiellaoxytoca: An impact of biofield treatment. (2015) J Microb Biochem Technol 7: 203-206. PubMed | CrossRef $\mid$ Others

38. Nayak G, Altekar N. Effect of biofield treatment on plant growth and adaptation. (2015) J Environ Health Sci 1(4): 1-9. PubMed | CrossRef $\mid$ Others

39. Trivedi, M.K., Patil, S., Shettigar, H., et al. In vitro evaluation of biofield treatment on cancer biomarkers involved in endometrial and prostate cancer cell lines. (2015) J Cancer Sci Ther 7: 253-257. PubMed | CrossRef $\mid$ Others

40. Singh, J., Trivedi, M.K., Branton, A., et al. Consciousness energy healing treatment based herbomineral formulation: A safe and effective approach for skin health. (2017) Am J Pharmacol Phytother 2(1): 1-10. PubMed |CrossRef $\mid$ Others

41. Smith, D.M., Trivedi, M.K., Branton, A., et al. Skin protective activity of consciousness energy healing treatment based herbomineral formulation. (2017) J Food Nutr Sci 5(3): 86-95. PubMed |CrossRef $\mid$ Others

42. Koster, D.A., Trivedi, M.K., Branton, A., et al. Evaluation of biofield energy treated vitamin $\mathrm{D}_{3}$ on bone health parameters in human bone osteosarcoma cells (MG-63). (2018) Biochem Mol Biol 3: 6-14.

PubMed |CrossRef $\mid$ Others

43. Trivedi, M.K., Sethi, K.K., Panda, P., et al. A comprehensive physicochemical, thermal, and spectroscopic characterization of zinc (II) chloride using X-ray diffraction, particle size distribution, differential scanning calorimetry, thermogravimetric analysis/differential thermogravimetric analysis, ultraviolet-visible, and Fourier transform-infrared spectroscopy. (2017) Int J Pharm Invest 7(1): 33-40.

PubMed | CrossRef | Others

44. Trivedi, M.K., Sethi, K.K., Panda, P., et al. Physicochemical, thermal and spectroscopic characterization of sodium selenate using XRD, PSD, DSC, TGA/DTG, UV-vis, and FT-IR. (2017) Marmara Pharm J 21(2): 311-318.

PubMed |CrossRef $\mid$ Others

45. Desktop X-ray Diffractometer "MiniFlex+". (1997) The Rigaku J 14: 29-36.

PubMed $\mid$ CrossRef $\mid$ Others

46. Zhang, T., Paluch, K., Scalabrino, G., et al. Molecular structure studies of (1S,2S)-2-benzyl-2,3-dihydro-2-(1Hinden-2-yl)-1H-inden-1-ol. (2015) J Mol Struct 1083: 286-299. PubMed | CrossRef | Others

47. Langford, J.I., Wilson, A.J.C. Scherrer after sixty years: A survey and some new results in the determination of crystallite size. (1978) J Appl Cryst 11(2): 102-113.

PubMed | CrossRef $\mid$ Others

48. Trivedi, M.K., Branton, A., Trivedi, D., et al. A systematic study of the biofield energy healing treatment on physicochemical, thermal, structural, and behavioral properties of iron sulphate. (2017) Int J Bioorganic Chem 2(3): 135-145.

PubMed |CrossRef $\mid$ Others

49. Sun, J., Wang, F., Sui, Y., et al. Effect of particle size on solubility, dissolution rate, and oral bioavailability: Evaluation using coenzyme $\mathrm{Q}_{10}$ as naked nanocrystals. (2012) Int J Nanomedicine 7: $5733-5744$.

PubMed | CrossRef $\mid$ Others

50. Khadka, P., Ro, J., Kim, H., et al. Pharmaceutical particle technologies: An approach to improve drug solubility, dissolution and bioavailability. (2014) Asian J Pharm 9: 304-316.

PubMed |CrossRef $\mid$ Others

51. Trivedi, M.K., Branton, A., Trivedi, D., et al. Evaluation of the impact of biofield energy healing treatment (the Trivedi Effect ${ }^{(\mathbb{B}}$ ) on the physicochemical, thermal, structural, and behavioural properties of magnesium gluconate. (2017) Int J Nutr Food Sci 6(2): 71-82.

PubMed |CrossRef $\mid$ Others

52. Savjani, K.T., Gajjar, A.K., Savjani, J.K. Drug Solubility: Importance and Enhancement Techniques. (2012) ISRN Pharmaceutics 2012: 195727.

PubMed | CrossRef $\mid$ Others

53. Mello, G.S., Cardoso, A.P., Oliveira, E.W.R.S., et al. Tryptophan. A proposal of the mechanism of thermal decomposition. (2015) J Therm Anal Calorim 122:1395-1401.

PubMed | CrossRef | Others

54. Mullany, L.C., Newton, S., Afari-Asiedu, S., et al. Cumulative effects of heat exposure and storage conditions of Oxytocin-inUniject in rural Ghana: implications for scale up. (2014) Glob Health Sci Pract 2(3): 285-294.

PubMed | CrossRef | Others

55. Jodar, K.S.P., Balcao, V.M., Chaud, M.V., et al. Development and Characterization of a Hydrogel Containing Silver Sulfadiazine for Antimicrobial Topical Applications. (2015) J Pharm Sci 104(7): 2241-2254.

PubMed | CrossRef $\mid$ Others

56. Gheorghe, D., Neacsu, A., Contineanu, I., et al. A calorimetric study of L-, D- and DL-isomers of tryptophan. (2017) J Therm Anal Calorim PubMed $\mid$ CrossRef $\mid$ Others

57. Zhao, Z., Xie, M., Li, Y., et al. Formation of curcumin nanoparticles via solution enhanced dispersion by supercritical $\mathrm{CO}_{2}$. (2015) Int J Nanomedicine 10: 3171-3181. PubMed | CrossRef $\mid$ Others

Submit your manuscript to Ommega Publishers and we will help you at every step:

- We accept pre-submission inquiries

- Our selector tool helps you to find the most relevant journal

- We provide round the clock customer support

- Convenient online submission

- Thorough peer review

- Inclusion in all major indexing services

- Maximum visibility for your research

Submit your manuscript at OMMEGA Publishers https://www.ommegaonline.org/submit-manuscript 